\title{
Popularizing eco-friendly textiles in urban India
}

\author{
SURABHI MAHAJAN
}

Received: 17.04.2014; Accepted: 10.11.2014

Author for correspondence:

\section{SURABHI MAHAJAN}

Department of Apparel and

Textile Science, College of Home

Science, Punjab Agricultural

University, LUDHIANA (PUNJAB)

INDIA

Email:surabhimahajanct@pau.edu
ABSTRACT : Fashion is the prevailing mode of expression. Fashions change more quickly than the culture as a whole. The present paper aims to explore the ways and means to popularize eco-friendly textiles in India and making them as a way of life. It is based on a survey of four of the leading textile manufacturing units and responses of 200 customers selected from all zones of Ludhiana city in the year 2010. The results showed that while manufacturers have the constraint of cost and acceptability by the customers, more than two-third customers lacked awareness about eco-friendly or green clothing. They also suggested that the awareness about these clothing, their ready availability and affordable cost may make them popular among the common people. It is suggested that government should organize informative programmes to make the public aware about eco-friendly/green clothing and should provide liberal subsidies to units engaged in manufacturing them.

KEY WORDS: Fashion style, Eco-friendly/green clothing, Synthetic clothing, Natural fibres,

口 HOW TO CITE THIS PAPER : Mahajan, Surabhi (2014). Popularizing eco-friendly textiles in urban India. Asian J. Home Sci., 9 (2) : 601-606. 